\title{
ANALISIS KOHERENSI KONSEP HUKUM NEWTON PADA SISWA KELAS X SMA NEGERI 5 PALU
}

\author{
Wildan Hasyim Amin, Darsikin, dan Unggul Wahyono \\ wildanhasyimamin@yahoo.com \\ Program Studi Pendidikan Fisika FKIP Universitas Tadulako \\ Jl. Soekarno Hatta Km.9 Kampus Bumi Tadulako Tondo Palu-Sulawasi Tengah
}

\begin{abstract}
Tujuan penelitian ini adalah untuk menganalisis koherensi konsep hukum Newton pada siswa kelas $X$ SMA Negeri 5 Palu. Subyek penelitian ini terdiri dari 18 orang siswa SMA Negeri 5 Palu Kelas X. Data diperoleh dari tes koherensi konsep hukum Newton dan wawancara langsung. Tes terdiri dari 3 teori dasar hukum Newton yaitu hukum Newton I, hukum Newton II dan hukum Newton III, tiap-tiap hukum terbagi atas 2 tema berbeda dan setiap tema dibuat 3 soal dengan representasi berbeda yaitu representasi verbal, grafik dan diagram sehingga jumlah soal keseluruhan adalah 18 butir soal. Data penelitian dianalisis melalui pendekatan deskriptif kualitatif. Skor hasil tes kemudian dikelompokan menjadi 3 kategori yaitu kategori tinggi, sedang, dan rendah. Masing-masing dari kategori, diambil 2 siswa perwakilan untuk diwawancara guna menggali informasi yang lebih mendalam. Hasil penelitian menunjukan bahwa tingkat koherensi konsep hukum Newton siswa menghasilkan rata-rata poin keseluruhan siswa 0,43 dengan poin tertinggi 0,83 dan terrendah 0,17 yang masih lebih rendah dibawah harapan. Siswa masih lemah dalam menjawab soal tes dengan representasi grafik dan verbal. Perlunya pembiasaan oleh siswa dalam menyelesaikan persoalan dalam suatu konsep fisika dengan menggunakan multi representasi yang beragam guna memperbaiki koherensi konsep yang dimiliki siswa terutama koherensi representasi.
\end{abstract}

Kata Kunci : Analisis, Koherensi, Konsep, Hukum Newton

\section{PENDAhUlUAN}

Diantara faktor yang mempengaruhi pemahaman fisika siswa adalah model matematika yang cenderung lebih diutamakan dibandingkan konsep itu sendiri. Pendidik tentu sudah sangat paham bahwa metematika sangat dibutuhkan dalam penguasaan suatu konsep fisika, namun kurang berbuat banyak untuk mempertajam pemahaman konsep siswa dan lebih menekankan pada pemahaman matematis. Banyak siswa tingkat menengah berupaya memehami konsep fisika dengan model metematis ${ }^{[1]}$.

Dengan pemahaman yang baik terhadap konsep-konsep dan prinsip-prinsip fisika, keterampilan siswa dalam memecahkan masalah-masalah fisika juga akan lebih baik. Rumus dalam fisika pada dasarnya adalah penurunan dari sebuah konsep. Penyelesaian soal fisika tanpa rumus di tingkat SMP atau SMA bisa dilakukan dan justru lebih mudah jika anak didik lebih memahami konsep ${ }^{[2]}$.

Siswa yang benar-benar memahami konsep dasar fisika suatu materi, akan mampu menyelasaikan berbagai macam soal fisika dalam kaitannya dengan teori tersebut baik soal itu berupa kontekstual maupun konseptual.
Suatu konsep yang lebih rumit akan dapat dipahami jika konsep yang lebih dasar telah dipahami. Kesulitan memahami konsep mengakibatkan konsep tersebut menjadi konsep sukar yang memungkinkan siswa mengalami salah konsep.

Salah satu dari beberapa kelemahan dari pemahaman konsep yang dimiliki oleh siswa adalah pemahaman konsep yang bervariasi dan tidak stabil. Dalam penelitian yang dilakuan oleh Frank untuk menyelidiki koherensi konsep yang dimiliki siswa dengan pemberian soal pilihan ganda menemukan bahwa, masih banyak siswa yang belum mampu mempertahankan konsep fisika yang dimilikinya untuk memecahkan beberapa permasalahan fisika dengan model yang berbeda dalam konseptual yang sama. Kebanyakan siswa dalam memecahkan masalah yang berbeda ini, dengan mudah mengubah pemikiran mereka yang menyebabkan mereka menjadi sulit untuk menjawab dan menyesatkan mereka ${ }^{[3]}$.

Peserta didik khususnya siswa SMA diharapkan dapat mengembangkan konsepkonsep fisika, sehingga mampu memahami dan menerapkannya dalam penyelesaianpenyelesaian persoalan fisika. Salah satu contoh materi yang memerlukan pemahaman konsep dalam pelajaran fisika adalah materi 
hukum Newton. Hal ini sesuai dengan standar kompetensi dari materi pokok hukum Newton yaitu menerapkan konsep dan prinsip dasar kinematika dan dinamika benda titik. Dalam materi ini peserta didik akan diukur kemampuannya dalam memecahkan persoalan mengenai penyebab gerak sebuah benda, faktor-faktor yang mempengaruhi geraknya, serta mengaplikasikannya untuk memecahkan berbagai persoalan gerak dalam kehidupan nyata. Dengan demikian penguasaan konsep hukum Newton merupakan hal yang sangat penting bagi peserta didik untuk dapat menyelesaikan persoalan fisika. Berdasar penelitian diatas, maka dilakukan penelitian yang bertujuan untuk menganalisis koherensi konsep hukum Newton pada siswa kelas X SMA Negeri 5 Palu.

\section{METODOLOGI PENELITIAN}

Jenis penelitian yang digunakan adalah penelitian kualitatif. Peneliti mengambil data secara langsung ditempat penelitian melalui observasi/pengamatan dan interview dengan objek yang telah ditetapkan. Penelitian menggunakan metode penelitian deskriptif, yaitu suatu metode yang digunakan untuk mendeskripsikan atau menggambarkan fenomena-fenomena yang ada, baik fenomena yang bersifat alami ataupun rekayasa manusia. Penelitian ini dilakukan untuk memperoleh gambaran tentang sesuatu keadaan secara objektif $^{[4]}$.

Subjek penelitian ini adalah siswa kelas $X$ SMA Negeri 5 Palu tahun ajaran 2014/2015 sejumlah 18 orang siswa dari 236 jumlah keseluruah siswa kelas $X$. Pemilihan siswa sebagai subjek penelitian ini didasarkan pada kebersediaan siswa tanpa paksaan untuk mengikuti tes koherensi kosep hukum Newton.

Responden penelitian yang menjadi sumber data kualitatif dipilih 6 orang siswa dari 18 orang siswa dengan teknik penentuan responden berdasarkan skor jawaban tes koherensi konsep siswa, yang mewakili tiga kategori yaitu kategori tinggi, sedang dan rendah. Setiap kategori diwakili oleh 2 orang siswa. Dua siswa untuk kategori tinggi, 2 siswa untuk kategori sedang dan 2 siswa untuk kategori rendah.

Untuk memperoleh data yang diperlukan pada penelitian ini maka peneliti menggunakan instrumen penelitian berupa tes yang berbentuk butir-butir soal pilihan ganda koherensi konsep multi representasi tentang hukum Newton. Tes koherensi konsep multi representasi tentang hukum Newton ini merupakan tes yang digunakan untuk dan menerapkan sebuah konsep secara fleksibel, dimana konsep dasar dari hukum newton pada sebuah konteks permasalahan yang sama disajikan menjadi beberapa butir-butir soal dengan representasi yang berbeda yaitu representasi verbal, grafik dan diagram. Pertanyaan-pertanyaan tes ini bersifat pemahaman dan untuk menjawabnya responden tidak perlu melakukan perhitungan atau menggunakan matematika.

Tes berbasis multi representasi pada penelitian ini berbentuk tes pilihan ganda dengan 6 konteks (tema) yang berbeda mengenai hukun Newton. Cakupan materi hukum Newton yang digunakan meliputi materi hukum Newton I, hukum Newton II, dan hukum Newton III. Dari setiap hukum, biambil masing-masing dua (2) tema. Dari setiap tema tersebut, kemudian dibuat mejadi 3 soal dengan konsep dan konteks yang dibuat semirip mungkin pada stemnya untuk setiap soal namun dengan representasi yang berbeda.

Berdasarkan jumlah materi yang terdiri dari 3 cakupan materi yaitu hukum Newton I, hukum Newton II, dan hukum Newton III, maka jumlah tema yang diangkat sebagai konteks dasar penyusunan soal adalah 6 tema. Untuk masing-masing tema dibuat menjadi 3 butir soal multi representasi, sehingga jumlah soal terdidri dari 18 butir soal.

Pembuatan butir-butri soal koherensi konsep hukum Newton siswa kemudian dilakukan seperti pada Gambar 1 :

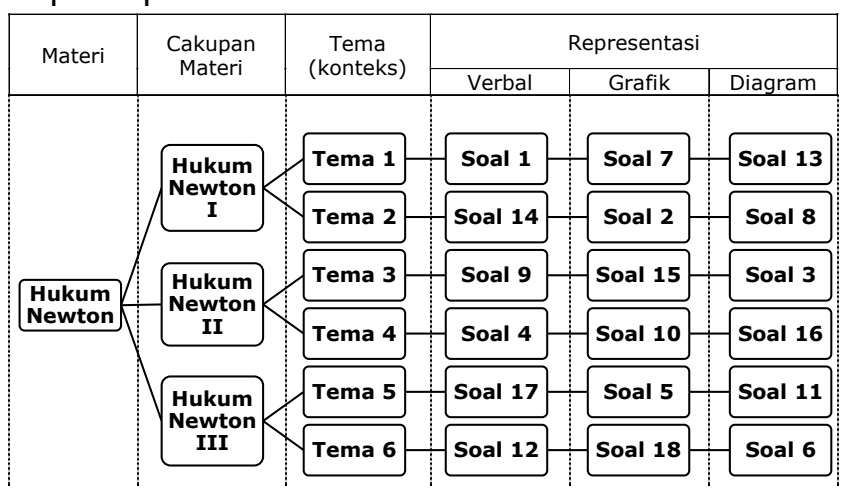

Gambar 1. Distribusi Soal

Wawancara ditujukan untuk mendapatkan informasi tentang koherensi konsep hukum Newton Siswa. Wawancara kemudian didokumentasikan melalui buku catatan dan alat perekam suara. Wawancara dilakukan pada responden yang terpilih.

Data yang diperoleh melalui wawancara mendalam, studi dokumentasi, dan ditunjang dengan pemberian tes, perlu dianalisis secara 
akurat dan seksama untuk diberi makna dan selanjutnya mengadakan reduksi data yang dilakukan dengan jalan membuat abstraksi.

Jawaban dari hasil tes koherensi konsep hukum Newton pada siswa kemudian dinalisis. Untuk menetukan nilai dari hasil tes koherensi konsep hukum Newton oleh siswa, poin jawaban responden dibagi menjadi tiga bagian, yaitu:

a) 2 poin (koheren), apabila memilih jawaban yang sesuai untuk 3 (tiga soal) pada tema yang sama dengan permasalahan yang berbeda.

b) 1 poin (kurang koheren), jika hanya menjawab 2 (dua) jawaban yang bersesuaian,

c) 0 poin (tidak koheren), jika hanya menjawab $\leq 1$ (satu) jawaban yang sesuai.

klasifikasi ini menyerupai klasifikasi tiga kali lipat untuk menggambarkan dinamika konseptual, yaitu proses dimana pandangan siswa diubah melalui instruksi [5]. Ketiga tingkatan ini diambil sebagai indikasi koherensi kosep dalam setiap pemberian dimensi dan representasi dari konsep hukum Newton. Tingkatan level pada pengkategorian ini menunjukan kebenaran dari koherensi konsep parsial. Tingkatan koherensi konsep ini juga sudah sesuai dengan tingkat koherensi kontekstual yang digunakan untuk data FCI

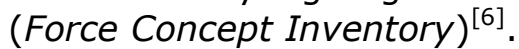

Pemberian poin pada siswa dilakukan dengan pemeriksaan pertema (perkonteks) soal. Jadi untuk setiap 3 soal dengan representasi yang berbeda dengan konteks yang sama pemberian poinnya 0,1 atau 2 poin. Jadi untuk soal yang terdiri dari 6 tema (konteks) soal maka jumlah poin siswa terdiri dari 6 jumlah poin dengan poin maksimal 12 poin.

\section{HASIL DAN PEMBAHASAN}

\section{A. HASIL}

Penelitian ini mengkaji mengenai koherensi konsep hukum Newton yang dimiliki oleh siswa kelas X SMA Negeri 5 Palu. Koherensi konsep yang dimaksud menekankan pada aspek koherensi representasi. Tingkatan keherensi konsep yang dimiliki siswa diukur dengan menggunakan tes dalam bentuk tes pilihan ganda sebanyak 18 nomor soal. Tes berbasis multi representasi. Pada penelitian ini tes berbentuk pilihan ganda dengan 6 konteks (tema) yang berbeda mengenai hukum Newton. Cakupan materi hukum Newton yang digunakan meliputi materi hukum Newton I, hukum Newton II, dan hukum Newton III. Dari setiap materi, diambil masing-masing dua (2) tema. Dari setiap tema tersebut, kemudian dibuat mejadi 3 soal dengan konsep dan konteks yang dibuat semirip mungkin pada stemnya untuk setiap soal dan disajikan pada representasi berbeda yaitu verbal, diagram dan grafik. Selain itu, responden juga bersedia memberikan informasi terhadap hasil tes yang telah diberikan melalui kegiatan wawancara. Peran peneliti dalam hal ini adalah sebagai instrumen aktif. Adapun deskripsi hasil analisis terhadap koherensi konsep hukum Newton siswa adalah sebagai berikut.

Penentuan kategori tinggi, kategori sedang dan kategori rendah dilakukan dengan terlebih dahulu menghitung jumlah poin rata-rata dan standar deviasi. Dengan jumlah poin rata-rata dan standar deviasi, data hasil tes representasi kemudian dikelompokan menjadi tiga kategori yaitu kategori tinggi, kategori sedang dan kategori rendah. Skor rata-rata yang diperoleh adalah 0,4537 dan nilai standar deviasi adalah 0,2138 . Hasil ini menunjukan bahwa data yang diperoleh memiliki standar deviasi yang tinggi yang mana menggambarkan bahwa sebaran nilai data hasil tes koherensi konsep jauh dari nilai rata-ratanya.

Berdasarkan jawaban tes pemilihan responden yang berjumlah 18 nomor dipilih sebanyak 6 orang responden berdasarkan distribusi jawaban tes pemilihan responden siswa yakni :

1. Kategori tinggi; nilai $>(0,4537+0,2138)=$ nilai $>0,6675$

2. Kategori sedang; $(0,4537-0,2138 \leq$ nilai $\leq$ $0,4537+0,2138)=0,2399 \leq \quad$ Nilai $\leq$ 0,6675 .

3. Kategori rendah; nilai $<(0,4537-0,2138)=$ nilai $<0,2399$

Data mengenai hasil jawaban siswa, perolehan poin siswa, jumlah rata-rata poin siswa dan pengkategoriannya lebih jelas dapat dilihat pada Tabel 1 .

Tabel 1. Hasil Jawaban Siswa,

\begin{tabular}{|r|l|r|l|} 
No & $\begin{array}{c}\text { No. } \\
\text { Responden }\end{array}$ & $\begin{array}{c}\text { Rata-Rata } \\
\text { Poin }\end{array}$ & $\begin{array}{c}\text { Kategori } \\
\text { Nilai }\end{array}$ \\
\hline 1 & RM001 & 0,50 & Sedang \\
\hline 2 & RM002 & 0,17 & Rendah \\
\hline 3 & RM003 & 0,33 & Sedang \\
\hline 4 & RM004 & 0,83 & Tinggi \\
\hline 5 & RM005 & 0,67 & Sedang \\
\hline
\end{tabular}


ISSN 23383240

\begin{tabular}{|r|l|r|l|}
6 & RM006 & 0,50 & Sedang \\
\hline 7 & RM007 & 0,17 & Rendah \\
\hline 8 & RM008 & 0,67 & Sedang \\
\hline 9 & RM009 & 0,33 & Sedang \\
\hline 10 & RM010 & 0,17 & Rendah \\
\hline 11 & RM011 & 0,33 & Sedang \\
\hline 12 & RM012 & 0,67 & Sedang \\
\hline 13 & RM013 & 0,33 & Sedang \\
\hline 14 & RM014 & 0,33 & Sedang \\
\hline 15 & RM015 & 0,67 & Sedang \\
\hline 16 & RM016 & 0,83 & Tinggi \\
\hline 17 & RM017 & 0,33 & Sedang \\
\hline 18 & RM018 & 0,33 & Sedang \\
\hline
\end{tabular}

Perolehan Poin Siswa, Jumlah Rata-Rata

Poin Siswa Dan Pengkategoriannya

Rekapitulasi jumah siswa berdasarkan tingkat pengkategorian tinggi, sedang dan rendah dari hasil tes koherensi konsep hukum Newton disajikan pada Tabel 2.

Tabel 2. Rekapitulasi Jumlah Siswa dalam

\begin{tabular}{|c|c|c|}
\hline Ketegori & Jumlah Siswa & Persentase \\
\hline Tinggi & 2 & $11,11 \%$ \\
\hline Sedang & 13 & $72,22 \%$ \\
\hline Rendah & 3 & $16,67 \%$ \\
\hline Jumlah & 18 & $100 \%$ \\
\hline
\end{tabular}

Kategori Koherensi Konsep

Berdasar Tabel 1, enam siswa yang dipilih untuk menjadi responden yang akan diwawancarai guna menggali lebih dalam tentang koherensi konsep hukum Newton yang mereka miliki yang mendasari mereka dalam menjawab soal tes adalah sebagai berikut:

1. Kategori tinggi yaitu RM004 dan RM016

2. Kategori sedang yaitu RM008 dan RM013

3. Kategori rendah yaitu RM007 dan RM010

Rekapitulasi persentase jawaban benar siswa berdasar hukum, tema, dan soal dari hasil tes koherensi konsep hukum Newton disajikan Pada Tabel 3.

Tabel 3. Rekapitulasi Jawaban Benar Siswa

\begin{tabular}{|c|c|c|c|c|c|c|}
\hline 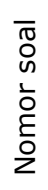 & $\begin{array}{l}\text { Hukum } \\
\text { Newton }\end{array}$ & Tema & 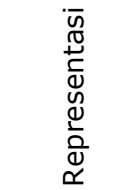 & 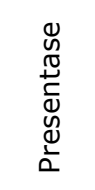 & 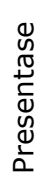 & 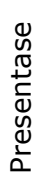 \\
\hline 1 & \multirow{6}{*}{$\begin{array}{l}\text { Hukum } \\
\text { I } \\
\text { Newton }\end{array}$} & \multirow{3}{*}{$\begin{array}{l}\text { Benda } \\
\text { Bergerak }\end{array}$} & Verbal & $28 \%$ & \multirow{3}{*}{$\begin{array}{l}28 \\
\%\end{array}$} & \multirow{6}{*}{$\begin{array}{l}40 \\
\%\end{array}$} \\
\hline 7 & & & Grafik & $33 \%$ & & \\
\hline 13 & & & Diagram & $22 \%$ & & \\
\hline 14 & & \multirow{3}{*}{$\begin{array}{l}\text { Benda } \\
\text { Diam }\end{array}$} & Verbal & $39 \%$ & \multirow{3}{*}{$\begin{array}{l}52 \\
\%\end{array}$} & \\
\hline 2 & & & Grafik & $17 \%$ & & \\
\hline 8 & & & Diagram & $100 \%$ & & \\
\hline
\end{tabular}

\begin{tabular}{|c|c|c|c|c|c|c|}
\hline 9 & \multirow{6}{*}{$\begin{array}{l}\text { Hukum } \\
\text { II } \\
\text { Newton }\end{array}$} & \multirow{3}{*}{$\begin{array}{l}\text { Perlamba } \\
\tan \end{array}$} & Verbal & $11 \%$ & \multirow{3}{*}{$\begin{array}{l}20 \\
\%\end{array}$} & \\
\hline 15 & & & Grafik & $6 \%$ & & \\
\hline 3 & & & Diagram & $44 \%$ & & \\
\hline 4 & & \multirow{3}{*}{$\begin{array}{c}\text { Kecepata } \\
\mathrm{n}\end{array}$} & Verbal & $67 \%$ & \multirow{3}{*}{$\begin{array}{l}76 \\
\%\end{array}$} & \\
\hline 10 & & & Grafik & $72 \%$ & & \\
\hline 16 & & & Diagram & $89 \%$ & & \\
\hline 17 & \multirow{6}{*}{$\begin{array}{l}\text { Hukum } \\
\text { III } \\
\text { Newton }\end{array}$} & \multirow{3}{*}{$\begin{array}{c}\text { Tambrak } \\
\text { an }\end{array}$} & Verbal & $28 \%$ & \multirow{3}{*}{$\begin{array}{l}30 \\
\%\end{array}$} & \multirow{6}{*}{$\begin{array}{l}25 \\
\%\end{array}$} \\
\hline 5 & & & Grafik & $44 \%$ & & \\
\hline 11 & & & Diagram & $17 \%$ & & \\
\hline 12 & & \multirow{3}{*}{$\begin{array}{c}\text { Doronga } \\
\mathrm{n}\end{array}$} & Verbal & $11 \%$ & \multirow{3}{*}{$\begin{array}{l}20 \\
\%\end{array}$} & \\
\hline 18 & & & Grafik & $28 \%$ & & \\
\hline 6 & & & Diagram & $22 \%$ & & \\
\hline
\end{tabular}

Dari Hasil Tes Koherensi Konsep

Rekapitulasi jawaban benar siswa berdasarkan format representasi dari soal tes disajikan dalam Tabel 3.

Tabel 4. Rekapitulasi Jawaban Benar Siswa Setiap Format Representasi

\begin{tabular}{|c|l|c|c|}
\hline No. & Representasi & $\begin{array}{c}\text { Jumlah } \\
\text { Jawaban } \\
\text { Benar }\end{array}$ & $\begin{array}{c}\text { Presentase } \\
\text { Jawaban } \\
\text { Benar }\end{array}$ \\
\hline 1 & Verbal & 33 & $30,6 \%$ \\
\hline 2 & Garfik & 36 & $33,3 \%$ \\
\hline 3 & Diagram & 53 & $49,1 \%$ \\
\hline \multicolumn{2}{|c|}{ Jumlah } & 122 & $37,7 \%$ \\
\hline
\end{tabular}

\section{B. PEMBAHASAN}

Dari hasil penelitian yang telah dipaparkan di atas, dapat diketahui bahwa tingkat koherensi konsep hukum Newton yang dimiliki oleh siswa sangatlah beragam dengan nilai rata-rata poin yang diperoleh dari keseluruhan siswa adalah 0,43, nilai ini menunjukan bahwa hasil perolehan poin dari tes koherensi konsep hukum Newton siswa masihlah tergolong rendah. Nilai ini juga menunjukan bahwa sebahagian besar siswa konsepnya tentang hukum Newton adalah tidak koheren. Untuk siswa dengan nilai rata-rata poin tertinggi hanya mampu berada dalam kategori kurang koheren konsep hukum Newtonnya.

Dari hasil ini pula dapat dikatakan bahwa sekitar $\pm 70 \%$ siswa tidak memiliki kemampuan menyelesaikan permasalahan fisika dengan representasi verbal, diagram maupun grafik. Hal ini tidak terlepas dari kebiasaan siswa dalam pembelajaran disekolah yang cenderung menggunakan format matematis dalam menyelesaikan masalah fisika, sehingga ketika 
siswa dihadapakan pada representasi berbeda yang bukan matematis, sebahagian besar siswa tidak dapat menyelesaikannya.

Berdasarakan hasil wawancara pada siswa terpilih (responden), dalam mengerjakan tes koherensi konsep hukum Newton responden masih belum mampu menggolongkan soal tes terhadap konsep dasar dari tes itu sendiri. Ketidakmampuan responden dalam menentukan konsep dasar yang berlaku pada soal mengakibatkan kesalahan mereka dalam menyelesaikan dan menjawab soal. Kebanyakan dari responden menjawab soal dengan hanya dengan mengira-ngira.

Ingatan responden tentang hubungan antara besar percepatan dengan gaya yang nilainya sebanding, juga mempengaruhi kemampuan responden pada penyelesaian tentang hukum Newton I tentang benda yang bergerak konstan. Kebanyakan responden berpikir bahwa benda yang bergerak selalu memiliki gaya, termasuk benda yang bergerak dengan kecepatan konstan. Hal ini bertentangan dengan hukum Newton I yang menyebutkan bahwa benda diam atau benda bergerak tanpa adanya percepatan (kecepatan benda konstan) memiliki $\Sigma F=0$. Hal ini juga dapat terlihat pada rendahnya persentase jawaban siswa pada materi Hukum Newton I tema benda bergerak pada Tabel 3.3 yang hanya memiliki persentase jawaban benar $27,8 \%$.

Hasil wawancara juga menunjukan bahwa kemampuan responden pada tema perlambatan meteri Hukum II Newton masih sangat rendah. Berdasar hasil wawancara terlihat bahwa anggapan responden hanya terfokus bahwa besarnya gaya sebanding hanya dengan percepatan benda bukan berdasar pada besarnya gaya yang diberikan sebanding dengan besar perubahan kecepatan yang terjadi, sehingga, ketika dihadapkan pada soal yang menyangkut pada perlambatan dan percepatan konstan, responden masih banyak mengalami kekeliruan. Responden masih menganggap percepatan dan kecepatan itu sama. Sementara untuk tema kecepatan dengan soal yang berkaitan dengan hubungan antara gaya dengan besar kecepatan, kemampuan siswa tergolong dalam ketegori baik, 75,9\% siswa mampu menjawab soal dengan benar.

Pada soal meteri hukum Newton III, responden selalu berpandangan bahwa pada saat tabrakan terjadi, benda yang memiliki kecepatan dan massa yang lebih besar memiliki gaya yang lebih besar pula. Konsep ini

sesungguhnya bertentangan dengan hukum Newton III dimana gaya aksi = gaya reaksi atau $F_{a k s i}=F_{\text {reaksi }}$ yang seharusnya kedua benda akan memberikan gaya yang sama besarnya. Hal ini juga berlaku pada peristiwa dorongan, kebanyakan pandangan siswa menyebutkan bahwa ketika terjadi doronggan, dianggap bahwa hanya benda yang mendorong yang memberikan gaya, sedangkan benda yang di dorong tidak memberikan gaya yang sama besarnya.

Multi representasi dalam tes dimaksudkan untuk melihat kemampuan siswa dalam menyelesaikan masalah dengan representase yang berbeda. Dari hasil wawancara beberapa responden menyebutkan bahwa kelemahan mereka berada pada penyelesaian soal dengan representasi grafik. Ketika dihadapkan pada soal yang berbentuk grafik siswa masih bingung dan menjawab tanpa konsep dasar yang benar dan hanya menerka-nerka jawaban.

Kemampuan responden dalam menjawab soal tes koherensi konsep yang rendah ini tidak terlepas dari hasil belajar siswa di sekolah mereka. Kebanyakan siswa belum paham benar dari konsep-konsep dasar hukum Newton, terlebih lagi penerapannya dalam menyelesaikan soal dengan konsep yang benar. Contoh-contoh soal yang diajarkan disekolah juga masih tergolong monoton yang lebih mengandalkan matematis sehingga mengakibatkan siswa belum mampu menyelesaikan permasalahan fisika dengan beragam representasi seperti representasi verbal, grafik dan diagram.

Untuk lebih meningkatkan koherensi konsep siswa khususnya koherensi representasi, siswa haruslah lebih dibiasakan untuk menyelesaikan soal dengan format representasi yang beragam seperti grafik dan diagram pada pembelajran disekolah. Kecenderungan menggunakan format representasi yang monoton pada pembelajaran akan mengakibatkan lemahnya kemampuan siswa jika dihadapkan pada penyelesaian soal yang lebih beragam. Dengan menggunakan berbagai representasi dalam pembelajaran akan lebih menunjang untuk penguatan dan peningkatan pemahaman konsep yang dimiliki oleh siswa itu sendiri, meskipun memang dibutuhkan waktu yang lebih untuk membahas atau menggunakan berbagai representasi dalam satu pokok bahasan pembelajaran.

\section{KESIMPULAN}


Berdasarkan data hasil penelitian, pengolahan data, analisis dan pembahasan maka dapat diperoleh kesimpulan sebagai berikut :

1. Tingkat Koherensi konsep hukum Newton siswa kelas $X$ SMA Negeri 5 Palu menghasilkan rata-rata poin untuk keseluruhan siswa adalah 0,43 dari dari nilai maksimal poin 2,0 dengan nilai tertingi 0,83 dan terendah 0,17 . Hasil ini menunjukan bahwa tingkat koherensi siswa masihlah tergolong rendah. Beberapa faktor yang mempengaruhi adalah : pada konsep tentang hukum Newton I kesalahan responden berpikir bahwa benda yang bergerak selalu memiliki gaya, termasuk benda yang bergerak dengan kecepatan konstan. Pada konsep tentang hukum Newton II responden masih menganggap percepatan dan kecepatan itu sama, pemahaman responden juga belum mampu berdasar pada besarnya gaya yang diberikan sebanding dengan besar perubahan kecepatan yang terjadi. Sedangkan pada konsep tentang hukum Newton III responden masih berpandangan bahwa pada saat tabrakan terjadi, benda yang memiliki kecepatan dan massa yang lebih besar memiliki gaya yang lebih besar pula dan pada peristiwa dorongan, dianggap bahwa hanya benda yang mendorong yang memberikan gaya.

2. Tingkat Koherensi Konsep siswa berdasarkan kategori menghasilkan 11,11\% pada ketegori tinggi, $73,22 \%$ pada kategori sedang dan $16,67 \%$ pada kategori rendah.

3. Tingkatan kemampuan siswa dalam menjawab soal multi representasi berturutturut adalah diagram $(49,1 \%)$, garfik $(33,3 \%)$, verbal $(30,6 \%)$.

\section{DAFTAR PUSTAKA}

[1]. Nashon, S. M. (2006). A proposed model for planning and implementing high school physics instruction. Juornal of Physics Teacher Education Online, 3(1)25-32

[2]. Surya. Y. (2006). IPA Dibuat Asyik. Jakarta: Armandelta Selaras.

[3]. Frank, B.W. (2012). Interactional Processes For Stabilizing Conceptual Coherences In Physics. Physical Review Special Topics - Physics Education Research 8, 020101

[4]. Sugiyono. (2004). Metode Penelitian Bisnis, CV. Bandung: Alfabeta

[5]. Thornton, R. (1995). Conceptual dynamics: Changing students views of force and motion. In C. Tarsitani, C.
Bernandini and M. Vincentini (Eds.). Thinking Physics for Teaching 157-183.. London: Plenum.

[6]. Savinainen, A., and Viiri, J. (2008). The Force Concept Inventory as a Measure of Students Conceptual Coherence. International Journal of Science and Mathematics Education 11/2008; 